\title{
HSE
}

Historia Social y de la Educación

Social and Education History

Instructions for authors, subscriptions and further details:

http://hse.hipatiapress.com

\section{John Dewey: His Role in Public Scholarship to Educate for Peace}

Charles F. Howlett ${ }^{1}$, Audrey Cohan ${ }^{1}$

1) Molloy College (USA).

Date of publication: October 23 2016

Edition period: October 2016 - February 2017

To cite this article: Howlett, C.F. \& Cohan, A. (2016). John Dewey: His role in public scholarship to educate for peace. Social and Education History 5(3), 203-222. doi:10.17583/hse.2016.2097

To link this article: http://dx.doi.org/10.17583/hse.2016.2097

\section{PLEASE SCROLL DOWN FOR ARTICLE}

The terms and conditions of use are related to the Open Journal System and to Creative Commons Attribution License (CC-BY). 


\section{John Dewey: His Role in Public Scholarship to Educate for Peace}

Charles F. Howlett

Molloy College (USA)
Audrey Cohan

Molloy College (USA)

\section{Abstract}

As 2016 is the centennial of Dewey's most famous work, Democracy and Education (1916), it is important to consider Dewey's role in public scholarship to educate for peace. Critical to an in-depth understanding of Dewey is recognition that the early twentieth century marked a transformational period in his views about war and peace. This paper addressed Dewey's less known political and social ideas during the rise of the "modern" American peace movement. In addition, Dewey's views of the role of education in a globalizing world are discussed. The research presented directly reflects global conflicts following World War I, while highlighting the disparity between war and peace.

Keywords: John Dewey, peace education, democracy 


\section{John Dewey: Su Papel en el Conocimiento Público para Educar para la Paz}

Charles F. Howlett

Molloy College (USA)
Audrey Cohan

Molloy College(USA)

\section{Abstract}

Ya que en 2016 se cumple el centenario del trabajo más reconocido de Dewey, Democracia y Educación (1916), es importante tener en cuenta el rol que Dewey jugó en la creación de un conocimiento público para educar para la paz. Para comprender en profundidad la obra de Dewey es esencial reconocer que los inicios del siglo XX supusieron un periodo que transformaría su visión sobre la guerra y la paz. Este artículo abordan las ideas políticas y sociales menos conocidas de Dewey durante el ascenso del movimiento "moderno" pacifista norteamericano. Además, se discute la visión de Dewey en relación al rol de la educación en un mundo globalizado. La investigación que se presenta refleja de forma directa los conflictos globales de después de la I Guerra Mundial mientas que se destaca la disparidad entre guerra y paz.

Keywords: John Dewey, educación para la paz, democracia 
s an educational theorist, John Dewey's work continues to be widely read and discussed by both pre-service and in-service teachers. However, critical to an in-depth understanding of

Dewey is recognition that the early twentieth century marked a transformational period in his views about war and peace. His less known social and political ideas-particularly his conception of democracy as a way of life-have generated debate and challenges from both the conservatives and liberals alike. This paper recounts Dewey's role in the peace movement and addressed his philosophies as related to global events.

The objectives of this paper are twofold: (a) to examine how closely Dewey's activities coincided with the rise of the "modern" American peace movement; and (b) to analyze Dewey's view on the role of education in a globalizing world. Both objectives entailed an examination of cultural resources for promoting both individual and communal growth. The research presented in this paper (Boydston, 1969-1991) directly reflects the "global conflict - fueled by political, territorial, ethnic, and ideological disputes which beckoned United States' engagement" (AERA, 2015, p.1) following World War I and highlights the interplay of research and social analysis.

In the aftermath of the Great War, Dewey became an ardent intellectual spokesperson on behalf of liberal internationalism and world peace. A strong supporter of President Wilson's progressive war aims, Dewey became disillusioned in the aftermath of the wrangling, which took place among the victorious Allies at the Treaty of Versailles. During the 1920s, he devoted his intellectual capital to the Outlawry of War movement resulting in the passage of the 1928 Kellogg-Briand Pact renouncing war as an instrument of national policy. Between the World Wars he also strongly supported the Committee on Militarism in Education, a peace group that opposed the creation of Reserve Officers Training Programs in colleges and universities across the United States. In addition, Dewey provided his own views as to how schools should promote the concept of internationalism and further cooperation among nation-states. Although not an "absolute" pacifist, Dewey's ideas and actions were based on his understanding of pacifism as a realistic and educative instrument necessary for battling the militaristic values and philistine patriotic views within society. Specifically, he did not consider bellicose values conducive to the democratic way of life. 


\section{Howlett \& Cohan-Dewey: His role in public scholarship}

In terms of our discussion, Dewey had the opportunity to address the role of schooling and peace during his journey to the Far East in 1919-1921 (Clopton \& Ou, 1973). In one particular lecture he delivered while in China, "The Cultural Heritage and Social Reconstruction," Dewey promoted three ground rules that were necessary if the schools were to create a feeling of democratic cooperation and world citizenship. The first rule and basic aim of education was for the school to create good citizens. When asked by the Chinese students to define what he meant by "good citizen," Dewey responded by listing four qualifications of the good citizen: (1) be a good neighbor and a good friend; (2) be able to contribute to others as to benefit from other's contributions; (3) be one who produced rather than one who merely shared in the production of others, from an economic standpoint; and lastly, (4) be a good consumer. According to Dewey's humanitarian and socially conscious outlook on life a "good citizen" was a person who contributed to the well-being of society. Above all, a "good citizen" was also one who appreciated the values of peaceful living by contributing to and sharing with his fellow citizens the fruits of society.

Dewey's second rule encouraged educators to create an atmosphere of harmony and friendliness whereby a feeling of world citizenship could be generated through the schools by making "students want to fulfill their duties to society, not from compulsion, but by curiosity and willingness, and out of love for their fellow men" (Clopton \& Ou, 1973, p. 211). But perhaps the most important rule was his last one, which incorporated the desire to acquaint students with the nature of social life and to the needs of society, as well as to their preparation for meeting these needs. A knowledge of one's environment and a willingness to eliminate its unworthy features, Dewey reasoned, was the main source of educational inspiration for the student. Social reconstruction, he believed, required more than sentiment. It demanded a general understanding of the nature of the problem and a willingness to adapt to new ways of thinking. Carter (2010) further noted that Dewey encouraged "this notion of purposeful engagement with conflicts in society" (p. 190) and he felt it should be part of the relevant educational curriculum. In each case, therefore, Dewey impressed upon his Chinese students a necessity for education to enhance the social, political, economic, and cultural institutions of a democratic society. "The school is the instrument," he concluded, "by which a new society can be built, and 
through which the unworthy features of the existing society can be modified" (Clopton \& Ou, 1973, p. 211).

Upon his return to Columbia University, New York, Dewey began calling for a new kind of curriculum, which would explore the theme of nationalism within an international context. What this curriculum should develop and encourage, he contended, is an attitude of world patriotism, not chauvinistic nationalism. "The teachers in our schools, and the communities behind the schools," he told his students at Teachers College and readers in the Journal of Social Forces, "have a greater responsibility with reference to this international phase of social consciousness and ideals than we have realized. As we need a program and a platform for teaching genuine patriotism and a real sense of the public interests of our own community so clearly we need a program of international friendship, amity and good will" (Dewey, 1923, p. 516). He insisted unhesitatingly,

We need a curriculum in history, literature and geography, which will make the different racial elements in this country aware of what each has contributed and will create a mental attitude towards other people which will make it more difficult for the flames of hatred and suspicion to sweep over this country in the future, which indeed will make this impossible, because when children's minds are in the formative period we shall have fixed in them through the medium of the schools, feelings of respect and friendliness for the other nations and peoples of the world. (Dewey, 1923, p. 516)

Dewey's arguments further highlighted the disparity between the two ends: war and peace. In terms of war, education teaches people to accept selfish behavior, promote authoritarian methods of rule, ignore moralistic reasons for good behavior, encourage coercion in the name of patriotic conformity, and comply with patterns of structural violence. In contrast, education for peace fosters responsibility, openness, innovation, selfmotivation, cooperative behavior, and barrier-free opportunities to pursue individual interests for the common good.

Dewey's intent was not to intellectualize the subject. Establishing a peaceful world order would never be accomplished by simply providing information and developing intellectual virtues. What he suggested is that one of the most important responsibilities for schools is to foster moral self- 


\section{Howlett \& Cohan-Dewey: His role in public scholarship}

discipline and humanistic self-fulfillment. The lesson he, himself, learned from the war was how effective schools were in promoting a singular patriotism. The final grade, however, was a failure.

Teachers did not communicate to their students that the ultimate goal was not the rightness of America's involvement in the war but the establishment of a global community rejecting the resort to armed conflict. "From the standpoint of...education, a large portion of current material of instruction," Dewey wrote in 1922, "is simply aside from the mark." No wonder, he continued, "Our schools send out men meeting the exigencies of contemporary life clothed in the chain-armor of antiquity, and priding themselves on the awkwardness of their movements as evidences of deepwrought, time-tested convictions." Is it any wonder that pupils "are ripe to be gulled, or that their attitude is one which merely perpetuates existing confusion, ignorance, prejudice and credulity" (Ratner, 1929, pp. 779-780). Since the United States helped win the war it was now America's responsibility to tear away the clothing of "chain-armor antiquity" and proudly don the robes of lasting world peace.

In terms of analyzing the role of education in a globalizing world, moreover, Dewey's involvement in the 1920s Outlawry of War movement is quite illuminating. Here we see Dewey applying his philosophical and educational theories on behalf of the "modern" American peace movement. The attempt to find common ground between the supporters of the newlyestablished League of Nations and those seeking to renounce war through juridical means reached its apex in the 1920s. This effort would culminate in 1928 with the signing of the Kellogg-Briand Pact or, as it was popularly known in European circles, the Pact of Paris. The attempt to outlaw war highlighted the efforts of both conservative and radical peace activists in which there were those advocating a fairer, peaceable world perfecting existing political and social structures based upon a slow and deliberate change, and those urging a more transformative world. The more radical peace activists exhorted new social structures and a redesigned political order carried out by mobilizing mass public opinion to adopt more drastic measures in order to force quick change outside of the normal diplomatic channels. The resulting peace pact "became a cultural icon as much as a policy objective for the peace movement," (Limberg, 2014, p. 396) and one 
of its most noted supporters was Dewey. The Outlawry campaign became his major contribution to postwar liberal internationalist thought.

Earlier efforts to develop world order based on international law and arbitration had been undertaken prior to the outbreak of war in 1914. In fact, for a good part of the nineteenth century, arbitration was the primary goal of internationalists and leading peace societies in both the United States and Europe. The notion of arbitration had been approached from different angles, but all were focused on promoting an understanding in which nations would agree to submit their differences to an impartial arbiter prior to resorting to armed conflict (Patterson, 1976).

The Outlawry of War crusade was primarily a moralistic-legalistic approach to international diplomacy. Relying on the means of creating overwhelming public support for the program - an approach characteristic of the "modern" peace movement's grassroots composition - the Outlawry of War proponents had three objectives: (1) outlaw war as a legal method of settling international disputes; (2) establish a code of international law that all nations would adhere to; and (3) create a court of justice similar to the US Supreme Court, which would encourage each nation to surrender its own war criminals - no matter how influential - to an international tribunal. Specifically, the immediate aim was not to eliminate war but to delegitimize it as the court of last resort (Ferrell, 1953).

The driving force behind the Outlawry of War crusade was a rich Chicago lawyer by the name of Salmon O. Levinson. Levinson, a graduate of Yale Law School in 1888, had been a very successful corporation lawyer. Originally a staunch supporter of Wilson's plan for a League of Nations, Levinson had gradually become disillusioned by what took place at Versailles. His increasing disenchantment after 1919 led to his conclusion that the use of sanctions against a nation was the equivalent of war. He noted that it was ludicrous to attempt to outlaw and abrogate war while at the same time threatening it as a means of enforcement (Stoner, 1943).

In order to build intellectual support for his idea he enlisted Dewey's help. Given Dewey's penchant for engaging in public issues impacting upon the democratic way of life, Levinson believed that Dewey could apply his "method of intelligence" to the cause of world peace. Thus Dewey's version of the Outlawry idea entailed using the applied intelligence to build the requisite moral and political awareness, which would achieve the realization 


\section{Howlett \& Cohan-Dewey: His role in public scholarship}

(conceptually and in application) that the system of war is detrimental to the demands of any situation. This would require, Dewey believed, changing the existing thinking on war, which considered it a legitimate institution. A code of law and a court - as both a means and an end-coincided with his pragmatic approach to world politics. Thus, the means - the moral judgment to create a court - could be interconnected with the end - the political will to back the court's decisions. To Dewey's way of thinking, Outlawry was a constitutive act of public engagement designed to replace long held acceptance of the brutal struggle between one absolute authority with another. According to one Dewey biographer, Westbrook (1991), "For Dewey, outlawing war was both an end of and a means to the democratization of politics, not only in the United States but throughout the world" (p. 269).

His attraction to the crusade was based on a genuine desire to unite Levinson's $(1918,1918$ a) legalistic approach to peace with his own desire to redirect society's moral and ethical sentiments against war. He believed that "a re-organization of international relations would serve to harmonize the ethics of nations with those of individuals and thus help to civilize international life" (DeBenedetti, 1968, p. 4; DeBenedetti, 1980). Dewey was committed, moreover, to the belief that a community of enlightened members could actively participate in their own self-creation. Outlawry of War, as both a social instrumentality and diplomatic weapon, Dewey maintained, offered the public an opportunity to demonstrate its commitment to make world peace an actuality.

Thus, the basic theoretical premise as well as pragmatic argument undergirding Dewey's support for the Outlawry plan, rested upon his assumption that the means proposed to implement this new idea was an educated public opinion-cognizant of morality as justice formulated through standards of societal consciousness. This public understanding would then recognize the need for internationalism and cooperation among nations. Such cooperation would also function as the means for designing a treaty outlawing war when signed. Ultimately, the Code of Law and Supreme Court, when finally created, would become effective and enduring instruments of international peace. At no time did Dewey contemplate the "chimerical possibility" of successfully outlawing war by a mere juristic declaration or by legal excommunication. The function and effectiveness of 
a World Supreme Court, in Dewey's opinion, rested not upon enforcement of sanctions but upon developing educated moral and ethical judgments - the means - of humankind.

Clearly, Dewey considered the Outlawry movement as an extension of his democratic social psychology. For Outlawry to take hold only the right cultural conditions would have to be established in support of the kinds of behavior that integrate emotions, ideas, and desires disposed to peaceful coexistence - those educated moral judgments. Instead of perfecting the art of war, nations and their peoples need to perfect the art of peace. Outlawry can assist in establishing a proper image of the world as an interdependent whole directed by political decisions aided by reasoned psychological, economic, and sociological knowledge of the probable reactions of different political systems capable of waging war.

It was Dewey's primary intention to see to it that reason would take precedence over emotion and blind trust; Outlawry was just the first step in the legal battle against war. The objective of the program was to work on the minds and dispositions of the public. If more people were taught that war was a crime against humanity coercive measures to prevent its recurrence would no longer be needed. Understanding would replace fear, and agreement would replace distrust. Quite clearly, the problem was not what reprisals a nation must fear for considering acts of blatant aggression but the moral and ethical incompatibility in undertaking such a course. If the internationalism of the modern world, in both its economic and psychological, and its scientific and artistic aspects, was to be truly liberated and made articulate, Outlawry of War was the most realistic, indeed the only realistic, means for firmly establishing "an international mind to function effectively in the control of the world's practical affairs" (Dewey, 1923a, p. 9). Thus, it would appear that Dewey's identification, association, allegiance, and participation in the Outlawry of War crusade was in complete agreement with his pragmatic approach to international peace. Perhaps the late historian Curti (1967) put it best when he wrote:

If Dewey's dedicated devotion to this program seemed naively idealistic to some of his contemporaries as well as to historians, it was nevertheless an important testimony to his conviction that war might be eliminated if the world stopped thinking in terms of war and that an 


\section{Howlett \& Cohan-Dewey: His role in public scholarship}

unlimited national sovereignty contradicted both common sense and social and human needs. (p. 1117)

Dewey's philosophical investment in the Outlawry principle also demonstrates clearly how he attempted to connect his political and social thought to the larger goal of world peace. Philosophically, Dewey insisted that the key issue for any successful understanding to acceptance of Outlawry was to inquire why the pervasiveness of war as a legalized method was considered as an established political institution. He believed that the public was unaware of this fact and, as part of its knowledge base, accepted it as reality. Removing the theoretical obstacle to a full appreciation for the Outlawry concept required people to look beyond the political connection between war and law. It necessitated that individuals revise their long established thinking, so that legal methods be used against war rather than for it. His philosophy was directed at using the experiential, not knowledge, as the means to achieve an end to war.

Understanding Dewey's position (Martin, 2002) derived from his belief that there first needed to be a general recognition of the problem of war, which had been promoted by political concerns and defined as part of power politics. Based on past experience, alliances and military buildups indicate that power politics itself represents a series of steps to armed engagement; each aspect increases the chances of conflict between equally competing states. Once the process of inquiry created awareness to this fact then the second development in the mind would follow. It would be a solid body of belief and will that the rule of law against war would replace the longestablished political acceptance of the use of military force. It would mark an important step forward in resolving disputes between established countries that feel threatened by new ones on the rise. He considered the idea of Outlawry as a test to discover whether the will of the people would be for war or peace. It was not a matter of providing a solution to the problem, but a method for removing those theoretical obstacles, which prevented it from being addressed.

Quite simply, he argued in favor the method of intelligence for overcoming the theoretical road blocks, which proposed that knowledge is based on the public's experience of dealing with problems and improving the prospects of collective action as it pertains to human affairs. Dewey's application of democratic theory, as tied to the debate between diplomacy 
and Outlawry, rested upon the public's authority as the instrument for all judgments. Overly optimistic, he pinned his hopes in the method of intelligence so that the process of inquiry would lead to the realization that Outlawry in practice represented the culmination of public engagement and democratic deliberation.

Public engagement and democratic deliberation also involved his views regarding militarism in education. After World War 1 a concerted effort was undertaken by the United States Military to establish a Reserve Officers Program on college campuses. This attempt to inaugurate a new era in civilian-military relations - a result of the war psychology — culminated in the National Defense Act of 1920. The act itself was an ambitious plan for bolstering the nation's military, with the underlying aim of not getting caught off guard if the threat of war should once again become a reality. This initiative provided for the establishment of over three hundred ROTC units with about 125,000 students participating in the program on college campuses throughout the country. In addition to the creation of the ROTC program, another provision of the act provided for the construction of summer training camps for youths. The program, optimistically referred to as Universal Military Training, began to admit prospective recruits in 1922, offering a combination of military and civic instruction to ten thousand young men for a thirty-day period. The program was a two-year course in military subjects with weekly drill instruction. Upon graduation an individual trainee would automatically receive a commission in the US Army. Furthermore, efforts were also undertaken to establish a voluntary training program for public high school students during after school hours. Its purpose was to establish a bridge for promoting citizenship awareness for the children of the millions of new immigrants arriving in America (Ekirch, 1956).

A primary reason why Dewey opposed the militarization of schooling was his firm belief that discipline was unsuited to classroom purposes. He opposed the authoritarian practices of military training as well as the emphasis on rigid conformity to rote drills. Such techniques, he believed, were monotonous and boring. To Dewey, education should be a creative and self-developmental process; any form of strict discipline ran counter to his views on progressive education, and rigid uniformity was unacceptable. A sense of libertarian values plus a belief in a self-developmental form of 


\section{Howlett \& Cohan-Dewey: His role in public scholarship}

education oriented to a moral way of thinking accounted for Dewey's consistent opposition to militarism in education. In fact, one of the more distinctive features of his book How We Think (first published in 1910) was the emphasis he placed on the importance of moral thinking as an essential character trait - certainly in response to the world situation facing future generations of students. "They are not the only attitudes that are important [open-mindedness, whole-heartedness, responsibility] in order that the habit of thinking in a reflective way may be developed," he wrote. "But the other attitudes that might be set forth are also traits of character, attitudes that, in the proper sense of the word, are moral, since they are traits of personal character that have to be cultivated." In other words, thinking should not be a mechanical process but rather a matter of "how we should live our lives as moral agents if we are to think effectively" (Dewey, 1971, p. 53).

Clearly, the mechanical, non-cognitive aspects of military training were in direct opposition to Dewey's pedagogy. Dewey had long criticized existing practices in education for placing too much emphasis on the mere symbols of knowledge and for being reluctant to make sufficient use of positive, firsthand engagement with experience. He noted that direct contact with experiences fostering cooperation, not conformity, should be the basis for learning and understanding. Teaching the art of the martial spirit, he argued, elevates the mere symbols of knowledge related to that subjectswords, uniforms, guns, and glory - and reinforces them in a philistine way.

His views on the subject date as far back as the 1890s when he established the Laboratory School at the University of Chicago just when the apparent effects of urbanization on education were surfacing. The introduction of military subjects and forms of physical education reminded him of the detrimental effects of a mass urban system of public schooling, which required rigid structure to accommodate the influx of immigrant children. Dewey believed that militarization in education creates a mechanized and bureaucratic system of learning, a system that will lead only to unquestioned obedience to the state and those in positions of authority. Dewey feared that without the presence of freedom in this setting, students' abilities to think critically would be compromised.

In a 1916 New Republic article titled "The Schools and Social Preparedness," prior to American military intervention in the war, he took direct aim at the preparedness advocates by questioning their sincerity and 
underscoring the additional burden such a program would place on teachers and pupils. "A few years from now our state legislatures may be besieged by ardent advocates of international peace," he wrote, "who will guarantee the future amity of the world if all children can have a fourteen weeks' course of lessons in 'peace."' Certainly, in light of the war, Dewey carefully considered the role that high school students might play, but he could not accommodate the idea that schools would be integral to the war effort: "Just now, however, the clamorers for preparedness have the speaker's eye, and two or three hours a week of drill exercise is to be made compulsory in high schools. ... All of this mechanical confidence in the mechanics of school programs is an ironic tribute to our national faith in the efficacy of education. Meantime it is hard on the schools." The results of such legislation will be "overburdened schools with...distracted teachers and pupils" standing "a good chance of being offered up a sacrifice on the altar of 'act first and think afterwards"' (Ratner, 1929, pp. 474-475).

Dewey championed the view that "[w]e are a pacific people and in the main a kindly disposed one; we regret the loss of life, the flames of hatred in Europe," although this would be transformed a year later with American military intervention in World War I. Dewey was slowly preparing the groundwork for future peace education endeavors, which he would undertake in the war's aftermath: "Unless the methods of critical discrimination which they [universities] foster extend into our secondary schools and thence, indirectly at least, into the elementary schools, we shall find democratic control tied to a course of inert drift alternating with periods of excited explosion. To make our schools the home of serious thought on social difficulties and conflicts is the real question of academic freedom, in comparison with which the topic which we have hitherto dealt with under that head is indeed academic." Fostering social change and freedom to act independently is the academic mission of schooling: "A nation habituated to think in terms of problems and of the struggle to remedy them before it is actually in the grip of forces which create the problems, would have an equipment for public life such as has not characterized any people." There is absolutely nothing wrong, he insisted, with connecting "this intellectual habit with coherent thinking in matters of foreign relations" (Ratner, 1929, pp. 474-475).

His consistent belief that militarism in schools perverts the positive 


\section{Howlett \& Cohan-Dewey: His role in public scholarship}

aspects of nationalism as a unifier of different cultures and understanding led to his direct involvement in the Committee on Militarism in Education, established in 1925. As a pubic intellectual Dewey worked with the committee in its efforts to accomplish two specific objectives: to act as a lobbying group seeking legislation to prohibit federal funds for compulsory military training courses for ROTC units on campus and to function as an educational propaganda agency. "We are now faced," he wrote prior to the committee's establishment, "by the difficulty of developing the good aspect of nationalism without its evil side; of developing a nationalism which is the friend and not the foe of internationalism." More importantly, he opined, "Since this is a matter of ideas, of emotions, of intellectual and moral disposition and outlook, it depends for its accomplishment upon educational agencies, not upon outward machinery. Among these educational agencies, the public school takes first rank" (Dewey, 1916/1980, p. 203).

Perhaps Dewey's most important educational contribution to the committee was lending his pen to composing introductory remarks to the organization's publications. For example, one of the final pamphlets published by the committee, Edwin C. Johnson's Mars in Civilian Disguise! (1939), Dewey wrote the foreword. Supporting Johnson's claim that the federal government's training program for student pilots is camouflage for "a definitely militaristic project," not a civilian one, Dewey launched into an unrestrained attack on the government's sincerity. "Public moneys," he charged, "are needed for the peaceful maintenance of an industrious and prosperous citizenship. But they are being diverted to the cause of war." By doing so, the methods employed by the federal government "strengthen the belief that the American opposition to war is being used by interested parties to sell the American people down the war-river. Under the name of defense, measures are proposed that have no sense unless the American people are being prepared to engage in war. Since the American people are opposed almost to a man to this idea, it is necessary to put blinders upon them in order to lead them toward war." Dewey cautioned readers to consider the response of institutions of higher learning as well: "Do they want the harnessing to be done under the claim that the measure is civilian? If persons in charge of colleges and universities favor this plan, what shall the American people with their strong opposition to being involved in war think about what the colleges and universities are doing?" (Dewey, 1939/1988, pp. 


\section{5-356).}

Dewey's contributions to post-World War I peace thought and to the subsequent development of peace education has largely been ignored by scholars. It should not be. Given the current state of world affairs, it is all the more stunning why those in the field of education have not taken a closer look at Dewey's intellectual contributions to peace thought and action. Regardless of his philosophical shortcomings in the political realm, belief in an altruistic human nature, and insistence that an educated public was capable of changing an entrenched political system, he nonetheless offered a different way of defining democracy: more fitting as an "instrument" of peace rather than making the world safe. He called for a civic engagement against war, noting that democracy is a disposition that seeks to bridge differences, form common interests, reflect critically on beliefs and values, and promote knowledge addressing the core challenges of a global village. As a public intellectual, Dewey separated himself from the application of disciplinary knowledge and expertise by insisting that passive communities become part of the public debate.

Dewey also helped make respectable the powerful secular impulse, which remodeled and reorganized the post-World War I peace movement. His call for peace between international states was tied to his seeking alternatives to institutionalized violence. He also aligned his thinking with radicalized nonpacifists who argued that war is less a social sin than it is a symptom of systemic social injustice. He legitimized the view that one does not have to be an absolute pacifist to be against war. He helped popularize the current feeling that one can still support their country but remain committed to promoting the idea of conflict resolution - not armed intervention-as the most desirable means for eradicating all forms of social oppression and disputes between nation states. In fact, since the Vietnam War this secularist attitude has grown and expanded to the point where, ideologically, many Americans subscribe to it.

Reevaluating his philosophy also made the transition easier for Dewey when he joined ranks with more liberal elements within the postwar peace movement. Reenergized and refocused, the "modern" peace movement witnessed a growing radicalization of pacifism; personal witness for peace became less inward and more outspoken in terms of social and political action. Liberal pacifism struck a responsive chord in Dewey's postwar 


\section{Howlett \& Cohan-Dewey: His role in public scholarship}

pragmatic approach to international politics and domestic reform. Traditional pacifists who had long asserted that the means determine the ends were in line with Dewey's philosophical position that ethical decisions, tied to nonviolent force, were now relative to the demands of time and place. Equally significant, the postwar peace reformers, condemning violence in contrast to the traditional dictates of nonresistance, were also willing to sanction some aspects of coercion as a means of redressing racial, social, and economic injustice.

As a matter of principle, the horrors associated with the destructiveness and massive casualties - combatant and civilian-of World War 1 had convinced him that war was an embodiment of collective behaviororchestrated and propagated by powerful interest groups who were able to influence the psychology of the masses in favor of armed conflictcorrupting the entire social order as well as its political structure. He thus began working from that principle to use his philosophy and educational theories to establish alternative means for resolving human conflicts and to develop forms of group harmony so that the means - the instrument of peace-might persist as an ongoing social dynamic in the lives of all individuals. In keeping with his understanding of the importance of community, moreover, he backed the concept of a global order for the larger society to emulate. And instrumentalism he viewed as a reform measure for replacing the political policies, social institutions, and cultural patterns that continued to prevent the triumph of lasting peace.

Antiwar activists, along with committed pacifists who now believed that peace required social reform as well as social order, tipped the scales in favor of Dewey's support. The modern (that is, postwar) peace activists were quick to point out that their predecessors represented an uncontroversial establishment reform effort. In their view American society and institutions would first have to fundamentally change if the United States wished to take a leading role in reforming international relations. More importantly, as historian Nigel Young (2013) observed, modern peace activists, not only added a moral dimension to their methods, but also "a theory of conflict and a dialectic of action in a struggle that became an 'experiment with truth': testing ideas through political dialogue, exemplary conduct, and communication during conflict, rather than through political violence. In the United States, Gandhi's ideas of nonviolent resistance blended with 
Reinhold Niebuhr's pacifism, John Dewey's pragmatism, and other strands of peace thought and civil disobedience" (Young, 2013, p. 160).

Furthermore, Dewey's rationale for supporting the "modern" peace movement as realistic, not utopian, is premised on his call for a democratized international system in which responsible policy makers would follow the lead of the public, managing peace through applied social justice and world agencies. The "modern" movement also rejected the "sentimental" nationalism of the prewar peace movement and the exclusivity of national self-determination in favor of a "higher" nationalism, which responded to the collective wisdom of the modern populace. Dewey certainly appreciated the "modern" peace movement's grassroots militancy and secularism as realistic alternatives to state-sponsored war; its increased acknowledgment of the economic causes of war; its willingness to challenge social elitist tendencies, within and without the movement; and its determination to initiate direct political, nonviolent action from the bottom up. The movement represented a desire to experiment with new ideas and tactics to accomplish its goals of world peace and social justice. Dewey's support was also tied to his realization that the United States could not escape the violence of modern war unless Americans were willing to assist in the reordering of international relations to mitigate national rivalries before they broke the chains of interdependence and drew the nation into another global conflict. He was indeed aware that public sentiment for building a lasting world peace was sincere and genuine, and he sought to cash in on it.

Instructively, it is incumbent upon readers to revisit Dewey's (1916) magnum opus, Democracy and Education, to capture the essence of his perception of national sovereignty, which he considered a major impediment to world peace. At the time he was writing this work he observed that,

Each [nation] is supposed to be the supreme judge of its own interests, and it is assumed as a matter of course that each has interests which are exclusively its own. To question this is to question the very idea of national sovereignty which is assumed to be basic to political practice.... (p. 97)

But that is exactly what he called upon educators to do for, 
This contradiction...between the wider sphere of associated and mutually helpful social life and the narrower sphere of exclusive and hence potentially hostile pursuits..., exacts of educational theory a clearer conception of the meaning of 'social' as a function and test of education than has yet been attained (Dewey, 1916, p. 98)

The message he left for future generations of educators for peace was for them to alter the environmental forces elevating the principle of national sovereignty as inviolable and replace it, as noted by him previously, with "...whatever binds people together in cooperative pursuits...apart from geographical limitations...[and the] provisional character of national sovereignty in respect to the...more fruitful association of intercourse of all human beings with one another must be instilled as a working disposition of the mind" (p. 98).

\section{Notes}

This article is based, in small part, upon a much larger study of Dewey's peace activism published by Southern Illinois University Press (2016) and is entitled, John Dewey, America's Peace-Minded Educator.

\section{References}

American Educational Research Association. (2015). 2016 Annual meeting call for submissions. Retrieved from http://www.aera.net/EventsMeetings/AnnualMeeting/2016AnnualMeetin gTheme/tabid/15861/Default.aspx

Boydston, J. A. (Ed.). (1969-1991). The collected works of John Dewey, 1882-1953. Carbondale, IL: Southern Illinois University Press.

Carter, C. C. (2010). Teacher preparation for peace education. In C. C.

Carter (Ed.), Conflict resolution and peace education (pp. 187-200). New York, NY: Palgrave Macmillan.

Clopton, R. W., \& Ou, T. C. (Eds.). (1973). John Dewey: Lectures in China, 1919-1920. Honolulu, HI: University of Hawaii Press.

Curti, M. (1967). John Dewey and nationalism. Orbis, 10, 1109-1117. Curti, M. (1968). The roots of American loyalty. New York, NY: Atheneum. 
DeBenedetti, C. (1968). American internationalism in the 1920's: Shotwell and the Outlawrists. (Unpublished doctoral dissertation). University of Illinois, Chicago: IL.

DeBenedetti, C. (1980). The peace reform in American history.

Bloomington, IN: Indiana University Press.

Dewey, J. (1916). Democracy and education. New York, NY: Macmillan.

Dewey, J. (1916/1980). Nationalizing education. In J. A. Boydston (Ed.),

The middle works of John Dewey, Vol. 10, (pp. 202-210). Carbondale,

IL: Southern Illinois University Press.

Dewey, J. (1923). The schools as a means of developing a social

consciousness and social ideals in children. Journal of Social Forces, 1,

513-517. Retrieved from https://www.jstor.org/stable/3005121

Dewey, J. (1923a). Outlawry of war: What it is and is not. Chicago, IL:

American Committee for the Outlawry of War.

Dewey, J. (1939/1988)] [1988]. Foreword to Johnson's Mars in civilian disguise! In J. A. Boydston (Ed.), The later works of John Dewey, Vol.

14, (pp. 355-356). Carbondale, IL: Southern Illinois University Press.

Dewey, J. (1971 rev.) How we think. Chicago, IL: Henry Regnery Co.

Ekirch, A. A. (1956). The civilian and the military. New York, NY: Oxford University Press.

Ferrell, R. E. (1953). Peace in their time: The origins of the Kellogg-Briand Pact. New Haven, CT: Yale University Press.

Levinson, S. O. (1918, March 9). The legal status of war. New Republic, 16, 171-173.

Levinson, S. O. (1918a, December 9, 1918). [Salmon O. Levinson papers].

Joseph R. Regenstein Library, University of Chicago, Chicago IL.

Limberg, M. (2014). In relation to the Pact: Radical pacifists and the

Kellogg-Briand Pact, 1928-1929. Peace \& Change, 39(3), 395-420. doi:

10.1111/pech.12079

Martin, J. (2002). The education of John Dewey: A Biography. New York,

NY: Columbia University Press.

Patterson, D. S. (1976). Toward a warless world: The travail of the American peace movement, 1887-1914. Bloomington, IN: Indiana University Press.

Ratner, J. (Ed.). (1929). Characters and events. Vol. II. New York, NY: Henry Holt \& Co. 
222 Howlett \& Cohan-Dewey: His role in public scholarship

Stoner, J. E. (1943). S. O. Levinson and the Pact of Paris. Chicago, IL: University of Chicago Press.

Westbrook, R. (1991). John Dewey and American democracy. Ithaca, NY: Cornell University Press.

Young, N. (2013). Concepts of peace: From 1913 to the present. Ethics and

International Affairs, 27, 157-173. doi: 10.1017/S0892679413000063

Dr. Charles F. Howlett. Professor, education división. Molloy College (USA)

Audry Cohan. Professor, education division. Molloy College (USA)

Contact Address: Acohan@molloy.edu 